\title{
Adolescent's Self-efficacy for Early Marriage in South Bangka Regency, Indonesia
}

\author{
Antarini $^{1}$, Putri Rhadiyah ${ }^{2}$, Tesza Permata $^{3}$, Rizka Marcely $^{4}$, Dini Montovani ${ }^{5}$ \\ $1,2,3,4,5$ Department of Midwifery, Health Polytechnic of Pangkalpinang, Central Bangka, Indonesia
}

\begin{tabular}{l}
\hline \hline Article Info \\
\hline Article history: \\
Received Aug 8, 2016 \\
Revised Nov 20, 2016 \\
Accepted Nov 26, 2016 \\
\hline
\end{tabular}

Keyword:

Adolescent

Early marriage

Indonesia

Self-efficacy

\begin{abstract}
The percentage of married women under the age of 20 years at $13 \%$ with a median age of 20.1 years and the median marriage age of first marriage in the rural lower at 19.7. Pregnancy at a very young age correlated with maternal mortality and morbidity. Girls aged 10-14 are five times the risk of dying during pregnancy or childbirth compared to the age group of 20-24 years, while the risk is doubled in the age group of 15-19 years. This study aimed to analyze several variables that affect the self-forming efficacy of early marriages. The research was explanatory research with cross sectional design. The sample size was 241. Data analysis was performed using correlation analysis Somers. There were very weak positive correlation for Verbal Persuasion $(r=0.013)$, very weak negative correlation for vicarious experience $(\mathrm{r}=-0026)$ and emotional arousal $(\mathrm{r}=-0075)$, weak negative correlation between mastery experience factor $(r=-0035)$ with early marriage.
\end{abstract}

Copyright $@ 2016$ Institute of Advanced Engineering and Science. All rights reserved.

\section{Corresponding Author:}

Antarini,

Department of Midwifery,

Health Polytechnic of Pangkalpinang,

Telaga Biru I Desa Padang Baru, Pangkalan Baru, Central Bangka, Bangka Belitung Province, Indonesia.

Email: antarini22@gmail.com

\section{INTRODUCTION}

Reproductive health problems starting with their early marriage are in women aged 10-54 years old are 2.6 percent was first married at age less than 15 years old and 23.9 percent were married by the age of 15-19 years old. Indonesia is the 37th country with the highest number of early marriages in the world in 2007. For ASEAN level, the rate of early marriage in Indonesia is second largest after Cambodia [1].

The Board of National Population and Family Planning (BKKBN) has adopted a program that aims to curb the number of people that Maturation Age Marriage (PUP) which is an effort to increase the age at first marriage, so as to achieve the minimum age at marriage is 20 years old for women and 25 years old for men [2].

The age of first marriage (UKP) is an indicator of the start of a woman's chance of pregnancy and childbirth. Pregnancy at a very young age correlated with maternal mortality and morbidity. Girls aged 10-14 are five times the risk of dying during pregnancy or childbirth compared to the age group of 20-24 years, while the risk is doubled in the age group 15-19 years. Marriage at a young age increases the risk of miscarriage, obstetric fistula, cervical cancer and other problems. Marriage at a young age can also cause developmental disorders of personality and put the children born at risk for the incidence of violence, neglect, developmental delay, learning difficulties, behavioral disorders, and also tends to be a parent at an early age. Reaching consequences in many aspects of life would be an obstacle in achieving the Millennium Developmental Goal [3].

The data from Indonesian Demographic and Health Survey (IDHS) in 2012, the percentage of married women under the age of 20 years at $13 \%$ with a median age of 20.1 years and the median marriage 
age at first marriage in the rural lower at 19.7. The province with the percentage of early marriages (15-19 years), the highest was Central Kalimantan (52.1\%), West Java (50.2\%), and South Kalimantan (48.4\%), Bangka Belitung (47.9\%) and Central Sulawesi (46.3\%) [4].

Adolescent Reproductive Health Survey Indonesia (SKRRI) from 2002 to 2003, explained that the decision makers are themselves married couples (63\% female and $72 \%$ male), parent and themselves (33\% in women and $25 \%$ in men-Eighteen), as well as the parents alone (4\% of women and $3 \%$ of men) [5].

The results of the analysis conducted by BKKBN in 2012 about the study of early marriages in some provinces in Indonesia (South Kalimantan, Bangka Belitung, Central Sulawesi and West Java) to know that the South Bangka Regency Bangka Belitung province in the spotlight major in comparative analysis between districts. An important finding is obtained that the influence of modernization and changes in behavior, education was not a priority, the economic pressure, the weak role of traditional leaders and religious, weak government's role in dissemination, advocacy, policy planning, and synergy across sectors. From these findings, many adolescents who left school early marriage actually still at the age of Junior High School when the economy was booming the most rapidly due to mining [6].

On the other side of early marriage was seen to have a positive impact if done with good reason, namely the prevention of fornication (free sex). Although marriage at a young age has higher risks for both disorders of the reproductive organs, such as cervical cancer and bleeding during childbirth. Psychological disorders, vulnerable divorce, and issues of economic readiness. But certainly due to the young age of marriage for children still in school are forced to leave school (drop outs), either due to the psychological burden as well as the school rules that do not permit students to get married. Based on the task of development, an adolescent is at the stage of identity versus identity confusion. At that time young people must decide who he (existence), what and how he reaches his future. Therefore, the formation of identity in adolescents is important [7].

A strong belief in the ability to perform a behavior will increase the likelihood of the realization of behavior. Components that must be observed in analyzing the behavior of a person, i.e the individual factors, environmental factors, and behavioral factors. Personal factors that influence adolescent sexual behavior in adolescents, such as knowledge, self-esteem, self-efficacy, self-regulation, self-belief, and religiosity [8].

Some research has shown that individuals with high self-efficacy tend to set higher goals, have high aspirations and therefore more committed to achieving the goals set before [9]. Self-efficacy is very important for young people in an effort to improve health behaviors. Self-efficacy also affects how much effort someone while going to try something new and someone perseverance in overcoming obstacles that arise [10]. Based on this background, researchers interested in conducting research on factors that affect selfefficacy on early marriage in South Bangka Regency.

\section{RESEARCH METHOD}

This type of research was explanatory research with cross sectional design. The population in this study was all wives of couples doing early marriage (under 20 years) in South Bangka Regency in the year 2011 to 2015 accounted for 2185 couples. Samples taken by Proportional Random Sampling number of 241 respondents spread over seven District of South Bangka. The measured variable was self-efficacy as an independent variable that consists of Mastery Experience, Vicarious Experience, Verbal Persuasion and Emotional Arousal, while marriage at a young age as the dependent variable. Data were analyzed using descriptive statistics which used to report the results in the form of frequency distribution and percentage (\%) of each item. The bivariate analysis in this study using correlation analysis Somers which was appropriate non-parametric correlation used to analyze the correlation between two variables that had ordinal data scale.

\section{RESULTS AND ANALYSIS}

\subsection{Univariate analysis}

\subsubsection{Characteristics of respondents}

From Table 1 we can see the highest percentages of those who married in the age range 16-19 years/late adolescent category (85.89\%), Educational level of respondents, elementary school (37.76\%) and Junior High Schools (37.34\%), Educational Level of Parents was graduating from elementary school (48.55\%), Marital Status now is married and there are some who have been divorced, occupied as a Housewife (94.61\%), monthly family income ranges between IDR 500,000 - 1,000,000 (61\%). 
Table 1. The Characteristic of Respondent

\begin{tabular}{|c|c|c|c|}
\hline No & Characteristics & Number (person) & Percentage $(\%)$ \\
\hline \multirow[t]{4}{*}{1} & Age Group (years old) & & \\
\hline & 10-12 (Early Adolescent) & 1 & 0.41 \\
\hline & 13-15 (Middle Adolescent) & 33 & 13.69 \\
\hline & 16-19 (Late Adolescent) & 207 & 85.89 \\
\hline \multirow[t]{5}{*}{2} & Educational Level of Respondents & & \\
\hline & Unpassed Elementary School / Never school & 19 & 7.88 \\
\hline & Graduated from Elementary School & 91 & 37.76 \\
\hline & Graduated from Junior High School & 90 & 37.34 \\
\hline & Graduated from Senior High School & 41 & 17.01 \\
\hline \multirow[t]{5}{*}{3} & Educational Level of Parent & & \\
\hline & Unpassed Elementary School / Never school & 85 & 35.27 \\
\hline & Graduated from Elementary School & 117 & 48.55 \\
\hline & Graduated from Junior High School & 26 & 10.79 \\
\hline & Graduated from Senior High School & 13 & 5.39 \\
\hline \multirow[t]{3}{*}{4} & Marital Status & & \\
\hline & Married & 222 & 92.1 \\
\hline & Divorced & 19 & 7.9 \\
\hline \multirow[t]{4}{*}{5} & Occupation & & \\
\hline & Housewife & 228 & 94.61 \\
\hline & Private Employee & 1 & 0.41 \\
\hline & Enterpriser & 12 & 4.98 \\
\hline \multirow[t]{5}{*}{6} & Family Income per month & & \\
\hline & No Income & 5 & 2.07 \\
\hline & $<$ IDR 500.000 & 9 & 3.73 \\
\hline & IDR $500.000-$ Rp. 1.000 .000 & 147 & 61.00 \\
\hline & IDR 1.000 .000 & 80 & 33.20 \\
\hline
\end{tabular}

\subsubsection{Self-efficacy}

Table 2 shows the majority (54\%) of respondents believe that the high vicarious experience's factor (54\%) and Emotional Arousal's factors (55\%) have been the cause of early marriage.

Tabel 2. The Distribution of Self-Efficacy

\begin{tabular}{lllll}
\hline \multicolumn{2}{l}{ Independent Variable } & Category & $\mathrm{N}$ & $\%$ \\
\hline \multirow{2}{*}{1} & \multirow{2}{*}{ Vicarious Experience } & High & 130 & 54 \\
& \multirow{3}{*}{2} & Low & 111 & 46 \\
& \multirow{2}{*}{ Emotional Arousal } & High & 132 & 55 \\
& & Low & 109 & 45 \\
\hline
\end{tabular}

\subsection{Analysis bivariate}

Based on Table 3 of the analytical results obtained Somers correlative value of the correlation coefficient which states that there was a very weak negative correlation between Vicarious Experience's factor $(r=-0026)$ and Emotional Arousal's factor $(r=-0075)$ with early marriage.

Tabel 3. The Result of Somers Analysis

\begin{tabular}{|c|c|c|c|c|c|c|c|c|c|}
\hline & & & & & $\mathrm{Ea}$ & rriag & & & \\
\hline & Idependent Variable & Category & & $\begin{array}{l}y \\
\text { cent }\end{array}$ & & $\begin{array}{l}\text { le } \\
\text { cent }\end{array}$ & $\mathrm{Ad}$ & $\begin{array}{l}\text { e } \\
\text { cent }\end{array}$ & $\mathrm{r}$ \\
\hline & & & $\mathrm{n}$ & $\%$ & $\mathrm{n}$ & $\%$ & $\mathrm{n}$ & $\%$ & \\
\hline 1 & Vicarious & High & 1 & 0.4 & 16 & 6.6 & 113 & 46.9 & -0.026 \\
\hline 1 & Experience & Low & 0 & 0.0 & 16 & 6.6 & 95 & 39.4 & -0.020 \\
\hline 2 & Emotional Arousal & High & 0 & 0.0 & 16 & 6.6 & 116 & 48.1 & -0.075 \\
\hline & & Low & 1 & 0.4 & 16 & 6.6 & 92 & 38.2 & \\
\hline
\end{tabular}

\subsection{Discussion}

Self-efficacy will enable the growth of confidence in herself to help conduct its activities so that there are no barriers and obstacles of any kind. Confidence includes self-confidence, ability to adapt, self, cognitive capacity, intelligence and capacity to act in stressful situations. Self-efficacy gradually evolved continuously with increasing capacity and increasing experience hooked. 


\subsubsection{Vicarious experience}

Based on the results of the study, the majority ( $>65 \%$ ) of respondents stated that they marry young because mimic public figure who marry at a young age, seeing school friends who had married first and see a family member who was happily married at a young age.

Seeing the experience of family, friends, school or peer, and public figures who married young and successful, then one will tend to follow the way or style of the model and imitate other people's experiences with the hope to get the same success as well. Although not as much influence as in the mastery experience, modelling is a powerful influence on self-efficacy when people do not believe in herself. Some consequences of increased self-efficacy include increased accessibility of community resources and increase in health promotion [11].

An increase in the self-efficacy of adolescents may increase the likelihood that they make safe decisions regarding their sexual health. Increasing self-efficacy is only one part of the problem regarding adolescents making safe sexual health decisions [12]. With an increased selfefficacy, individuals were able to consistently perform the task and shows that they have the strength and certainty to perform the task [13].

Correlation test results showed a correlation of different directions very weak between the two variables. This means that the higher the experience of others, the marriage age is getting younger. Individuals who see other people or models that serve as an example or a figure idolized tend to marry at a young age for marriage is increasingly eager to experience the success of others.

According to the theory of efficacy, the successful experience of others who have similarities to the individual in a task usually will increase the efficacy of one's self in the same task. The efficacy is obtained through social models, which typically occurs in a person who is less knowledgeable about her ability to perform modelling [14].

Vicarious experiences involves observing someone perform a task, and then the individual feels comfortable performing the same task and receiving a positive outcome [15]. The adolescent who sees their peers making healthy sexual decisions is more apt to make healthy decisions regarding their own sexual health [16].

\subsubsection{Emotional arousal}

Based on the results of the study, the majority (> 70\%) of respondents stated that the number of marriages due to the young age at the discretion of the parents to be married. While the answer is deemed low due desire in fostering domestic life and reduce the burden on parents and avoid adultery.

Those results confirmed that the occurrence of child marriage follow the wishes of their parents for various reasons although it is actually not want to get married or married relationships. This will certainly affect a person psychologically, between following the wishes of parents and their own desires.

Correlation test results showed a correlation of different directions very weak between the two variables. This means that the higher the state of psychological factors, the age of marriage has matured. Individuals who have a stable psychological state tend to marry at the age of marriage is getting ripe for more careful and full consideration in deciding something.

In general, a person will tend to expect success in conditions that are not in the paint by the tension and do not feel any complaints or other somatic disorders. Self-efficacy is usually characterized by low levels of stress and anxiety (the psychological state was good). Additionally, included in the activation of psychological, mood also affects the feelings of self-efficacy, because the mood stirs someone's memory. Successes and failures of the past are stored in memory. Thinking positive mood moves on past achievements and success under positive mood produces a high level of self-efficacy [14].

Sometimes individuals judge their abilities based on their physical cues. These cues could be anxiety, fear, or any other physical cues. Before an individual can sense self-efficacy, they must be able to complete a task successfully, observe someone else perform a task with success, obtain positive feedback with regard to completing a task, or rely on physiological cues [15].

\section{CONCLUSION}

Results of univariate analysis known that most of the respondents were married at the age range of 16-19 years who are classified as late adolescents (85.89\%); Educational Level of Respondents was Elementary School (37.76\%) and Junior High Schools (37.34\%); Educational Level of Parents was graduating from elementary school (48.55\%) and Marital Status are married $(92.1 \%)$ and divorced $(7.9 \%)$. The results of the analysis Somers known that there was a very weak negative correlation between Vicarious Experience $(r=-0026)$ and Emotional Arousal $(r=-0075)$ with early marriage.

Improving efforts to cross-sector cooperation through the Government such as Department of Education, Department of Health, Ministry of Religious Affairs and Board of National Population and 
Family Planning (BKKBN) through socialization and counseling for adolescent's health sustainably; involving the participation of another party that involve youth and their parents.

\title{
ACKNOWLEDGEMENTS
}

The research was fully funded by the Board of National Population and Family Planning (BKKBN) Bangka Belitung Province, Republic of Indonesia.

\section{REFERENCES}

[1] Board of Health Research and Development Ministry of Health of the Republic of Indonesia, "Basic Health Research in 2013," Jakarta, the Ministry of Health of the Republic of Indonesia, 2013.

[2] BKKBN, "Grand Design Quantity Control of Population 2010-2035," Jakarta, National Population and Family Planning, 2011.

[3] Fadlyana E. and Larasaty S., "Marriage early age and its problems," Sari Journal of Pediatrics, vol/issue: 11 (2), pp. 136-40, 2009.

[4] BKKBN, "Province in Indonesia: Root of the Problem and Institutional Role in Region," Impact Analysis of Population Directorate of Population Family Planning Agency, Jakarta, 2012.

[5] BPS, "ORC Macro. Indonesian young adult reproductive health survey 2002-2003," Calverton, Maryland, USA, the Central Bureau of Statistics and ORC Macro, 2004.

[6] BKKBN, "Study of Early Marriage in Some Provinces in Indonesia," Jakarta, WG Socio-Economic Impact Assessment of the Population Ditdamduk BKKBN, 2012.

[7] J. W. Santrock, "Life-Span Development McGraw-Hill Higher Education," Boston, MA, 2008.

[8] D. F. Ragin, "Health Psychology an Interdisciplinary Approach To Health," Boston, Pearson, 2011.

[9] F. Ridhoni, "Methods Swap Experience to Improve Self-Efficacy in Drug Addicts," Journal of the Science and Practice of Psychology, pp. 226-239, 2013.

[10] K. J. Karren, et al., "Mind / Body Health. The Effect of Attitudes Emotions and Relationships," San Francisco, Benjamin Cummings, 2002.

[11] P. Block, et al., "Project shake-it-up: Using health promotion, capacity building and a disability studies framework to increase self-efficacy," Disability and Rehabilitation, vol. 32, pp. 741-754, 2010.

[12] M. Cothran and J. White, "Adolescent behavior and sexually transmitted diseases: The dilemma of human papillomavirus," Health Care for Women International, vol. 23, pp. 306-319, 2002.

[13] E. S. Hendriksen, et al., "Predictors of condom use among young adults in South Africa: The reproductive health and HIV research unit national youth survey," American Journal of Public Health, vol. 97, pp. 1241-1248, 2007.

[14] S. Azwar, "Scale Preparation of Psychology," Yogyakarta, Reader Learning, 2012.

[15] K. Zulkosky, "Self-efficacy: A concept analysis," Nursing Forum, vol/issue: 44(2), pp. 93-102, 2009.

[16] M. Jenkins, "A Concept Analysis of Self-Efficacy and Adolescent Sexual Risk-Taking Behavior," Nursing Forum, vol/issue: 50(1), 2015.

\section{BIOGRAPHIES OF AUTHORS}

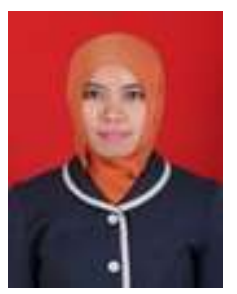

\author{
Name : Antarini, M. Kes \\ Place/date of birth $\quad:$ Koba/ September $22^{\text {nd }}, 1985$ \\ Present occupation : Lecturer \\ Mobile phone $\quad: 085268998534$ \\ Email : antarini22@gmail.com
}

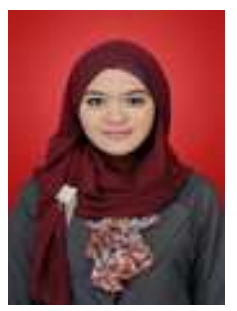

\section{Name $\quad$ : Putri Rhadiyah, S.ST}

Place/date of birth : Padang, September $1^{\text {st }}, 1991$

Present occupation : Instructor

Mobile phone : 085274835843

Email : rhadiyah@ymail.com 


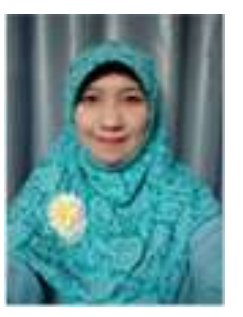

\section{Name : Rizka Marcely, S.ST}

Place/date of birth $\quad$ : Pangkalpinang, March $16^{\text {th }}, 1991$

Present occupation : Instructor

Mobile phone : 085267212241

Email : macely.rizka@yahoo.com

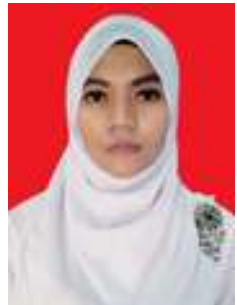

Name

: Dini Montovani, S.ST

Place/date of birth : Bukit Tinggi, December $25^{\text {th }}, 1990$

Present occupation : Instructor

Mobile phone

: 085263949781

Email

:dini25montovani@gmail.com 